\title{
Pengaruh Pengelolaan Kelas Terhadap Motivasi Belajar di Madrasah Ibtidaiyah Nurul Jihad Kecamatan Tembilahan Hulu
}

\author{
Nur Asisah ${ }^{1}$, Nasrullah ${ }^{2}$ \\ ${ }^{1}$ Pendidikan Guru Madrasah Ibtidaiyah, STAI Auliaurrasyidin, Tembilahan Riau, Indonesia \\ ${ }^{1}$ Pendidikan Guru Madrasah Ibtidaiyah, STAI Auliaurrasyidin, Tembilahan Riau, Indonesia \\ *Corresponding author: sishanurasisah@gmail.com \\ *Corresponding author: nasrullah@gmail.com
}

\begin{abstract}
Abstrak
Pengelolaan kelas adalah proses atau upaya yang dilakukan oleh seorang guru secara sistematis untuk menciptakan dan mewujudkan kondisi kelas yang dinamis dan kondusif dalam rangka menciptakan pembelajaran yang efektif dan efisien, sedangkan motivasi belajar adalah dorongan dari dalam diri murid dan dari luar diri murid untuk mengalami perubahan perilaku dalam bentuk pengetahuan, sikap, nilai dan keterampilan.

Penelitian ini bertujuan untuk mengetahui pengaruh pengelolaan kelas terhadap motivasi belajar siswa di MI Nurul Jihad Kecamatan Tembilahan Hulu. Populasi dalam penelitian ini adalah guru wali kelas pada kelas tinggi IV, V, VI dan siswa kelas tinggi di MI Nurul Jihad Kecamatan Tembilahan Hulu, dimana guru wali kelas pada kelas tnggi berjumlah 6 orang, dan siswa berjumlah 121 orang,untuk variabel $\mathrm{X}$ (pengelolaan kelas) peneliti tidak menggunakan sampel karena masih memungkinkan peneliti meneliti tiap populasi secara satu persatu. Sedangkan variabel Y (motivasi belajar siswa) menggunakan sampel sebanyak 24 siswa. Penelitian ini menggunakan 2 Variabel yaitu variabel bebas (pengelolaan kelas) dan variabel terikat (motivasi belajar siswa). Teknik pengumpulan data yang digunakan adalah observasi, angket, dan dokumentasi. Analisis yang digunakan adalah análisis uji t.

Hasil penelitian menunjukkan bahwa persentase pengelolaan kelas yang dilakukan oleh 6 guru wali kelas adalah $86,54 \%$ dengan kategori sangat baik, sedangkan persentase motivasi belajar siswa 62,5 dengan kategori baik. Kemudian hasil analisis uji $t$ menunjuk kan nilai thitung adalah $2,723 \geq$ ttabel adalah 1,679 .

Kesimpulan dalam penelitian ini adalah terdapat pengaruh yang signifikan antara pengaruh pengelolaan kelas terhadap motivasi belajar siswa di MI Nurul Jihad Kecamatan Tembilahan Hulu Tahun 2015.
\end{abstract}

Kata Kunci: Pengelolaan Kelas, Motivasi Belajar

\section{PENDAHULUAN}

"Belajar adalah kegiatan fisik atau badaniah. Untuk itu hasil yang dicapai adalah berupa perubahan-perubahan dalam fisik. Pendapat lain mengatakan bahwa belajar adalah kegiatan rohaniah atau psychis. Sasaran yang dicapai disini adalah 
perubahan-perubahan jiwa. Sementara pendapat tradisional, belajar adalah menambah dan mengumpulkan sejumlah pengetahuan". ${ }^{1}$

Ahli pendidikan modern merumuskan bahwa belajar adalah suatu bentuk pertumbuhan atau perubahan dalam diri seseorang yang dinyatakan dalam cara-cara bertingkah laku yang baru berkat pengalaman dan latihan. berdasarkan paparan diatas dapat disimpulkan bahwa inti pembelajaran itu adalah sebagai suatu proses perubahan tingkah laku pada diri individu berkat adanya interaksi antara individu dan individu dengan lingkungannya. ${ }^{2}$

Harapan yang tidak pernah sirna dan selalu guru tuntut adalah, bagaimana bahan pelajaran yang disampaikan guru dapat dikuasai oleh anak didik secara tuntas. Ini merupakan masalah yang cukup sulit yang dirasakan oleh guru. Kesulitan ini dikarenakan anak didik bukan hanya sebagai individu dengan segala keunikannya, tetapi mereka juga sebagai makhluk sosial dengan latar belakang yang berlainan. Ada tiga aspek yang membedakan anak didik yang satu dengan yang lainnya, yaitu aspek intelektual, psikologis, dan biologis.

Ketiga aspek tersebut diakui sebagai akar permasalahan yang melahirkan bervariasinya sikap dan tingkah laku anak didik disekolah. Hal itu pula yang menjadi tugas cukup berat bagi guru dalam mengelola kelas dengan baik. Keluhan-keluhan guru sering terlontar hanya karena masalah sukarnya mengelola kelas. Akibat kegagalan guru mengelola kelas, tujuan pembelajaran pun sukar untuk dicapai. ${ }^{3}$

Pengelolaan kelas adalah proses atau upaya yang dilakukan oleh seorang guru secara sistematis untuk menciptakan dan mewujudkan kondisi kelas yang dinamis dan kondusif dalam rangka menciptakan pembelajaran yang efektif dan eisien. ${ }^{4}$

Ruang kelas yang dikelola secara efektif adalah ruang kelas yang berlangsung dengan lancar, dengan sedikit sekali kebingungan dan keterhambatan, dan memaksimalkan kesempatan pembelajaran siswa. Tidak mungkin bagi seorang guru untuk menyelenggarakan pembelajaran, atau bagi para siwa untuk bekerja secara produktif, jika mereka tidak memeliki panduan tentang bagaimana mereka berperilaku, kapan dan bagaimana bergerak disekiter ruangan, dimana harus duduk, kapan mereka boleh dan tidak boleh menginterupsi guru, dan jumlah keberisikan yang bisa diterima. ${ }^{5}$

Sebagai pengelola kelas, guru hendaknya dapat mengelola kelas dengan baik, karena kelas adalah tempat berhimpun semua anak didik dan guru dalam rangka menerima bahan pelajaran dari guru. Kelas yang dikelola dengan baik akan menunjang jalannya interaksi edukatif. Sebaliknya, kelas yang tidak dikelola dengan baik akan menghambat kegiatan pengajaran. Anak didik tidak mustahil akan merasa bosan untuk

\footnotetext{
${ }^{1}$ Zainal Asril, Micro Teaching, (Jakarta: PT Rajagrafindo Persada, 2012), Cet. Ke-4, hlm. 1.

${ }^{2}$ Ibid.

${ }^{3}$ Syaiful Bahri Djamarah dan Aswan Zain, Stratei Belajar Mengajar, (Jakarta: Rineka Cipta, 2006), Cet. Ke-3, hlm. 1-2.

${ }^{4}$ Sulistyorini, Manajemen Pendidikan Islam, konsep,strategi dan aplikasi, (yogyakarta: Teras, 2009), hlm. 92.

${ }^{5}$ Carolyn M.Evertson dan Edmund T.Emmer, Manajemen Kelas Untuk Guru Sekolah Dasar, (Jakarta: Kencana, 2011), cet. ke-1. hlm. 26
} 
tinggal lebih lama dikelas. Hal ini akan berakibat menggannggu jalannya proses interaksi edukatif. Kelas yang terlalu padat dengan anak didik, pertukaran udara kurang, penuh kegaduhan, lebih banyak tidak menguntungkan bagi terlaksananya interaksi edukatif yang optimal. Hal ini tidak sejalan dengan tujuan umum dari pengelolaan kelas, yaitu menyediakan dan menggunakan fasilitas kelas bagi bermacam-macam kegiatan belajar mengajar agar mencapai hasil yang baik dan optimal. Jadi, maksud dari pengelolaan kelas adalah agar anak didik betah tinggal di kelas dengan motivasi yang tinggi untuk senantiasa belajar didalamnya. ${ }^{6}$

Pengelolaan kelas yang dilakukan dengan baik oleh guru, baik pengelolaan kelas yang bersifat fisik maupun pengelolaan kelas yang bersifat non fisik mampu membuat siswa termotivasi untuk belajar. Dan tentu kelas yang tidak dikelola dengan baik oleh guru, yang dimana siswa belajar di dalam kelas terasa gersang, membosankan dan tidak dapat menimbulkan motivasi belajar siswa.

Madrasah Ibtidaiyah Nurul Jihad Kecamatan Tembilahan Hulu, merupakan sekolah yang dimana pengelolaan kelas secara non fisik dapat dikatakan kedalam kategori baik. Hal tersebut dapat dilihat dari cara mengajar guru, akan tetapi pengelolaan kelas yang bersifat fisik belum dapat dikatakan baik. Hal itu dikarenakan masih ditemukannya beberapa hal, diantaranya: cara pengaturan tempat duduk yang kurang sesuai, kebersihan kelas yang kurang di jaga, serta keindahan kelas yang kurang ditata. Namun secara umum Madrasah Ibtidaiyah Nurul Jihad Kecamatan Tembilahan Hulu pengelolaan kelasnya baik, tetapi motivasi belajar siswanya masih rendah.

Berdasarkan studi pendahuluan yang penulis lakukan pada hari Senin tanggal 24 Februari 2014 di Madrasah Ibtidaiyah Nurul Jihad Kecamatan Tembilahan Hulu, yang dimana pengelolaan kelasnya sudah baik tetapi motivasi belajar siswanya masih rendah. Hal itu dapat dilihat dari gejala-gejala sebagai berikut: siswa yang suka permisi pada saat jam pembelajaran berlangsung, siswa yang tidak mau diam di tempat dan suka pindah-pindah saat mengerjakan tugas, siswa yang masih suka bercerita pada saat guru menjelaskan pembelajaran dan terlihat siswa yang masih malas-malasan saat belajar.

Dari gejala-gejala tersebut peneliti termotivasi untuk melakukan penelitian lebih lanjut, dengan mengajukan rumusan masalah sebagai berikut: Apakah terdapat pengaruh antara pengelolaan kelas terhadap motivasi belajar siswa pada kelas tinggi di Madrasah Ibtidaiyah Nurul Jihad Kecamatan Tembilahan Hulu Tahun 2015? Sedangkan tujuan penelitian yang penulis lakukan adalah untuk mengetahui apakah terdapat pengaruh antara pengelolaan kelas terhadap motivasi belajar siswa pada kelas tinggi di Madrasah Ibtidaiyah Nurul Jihad Kecamatan Tembilahan Hulu Tahun 2015.

\section{METODE PENELITIAN}

Secara operasional, metode yang digunakan dalam penelitian ini adalah sebagai berikut:

${ }^{6}$ Syaiful Bahri Djamarah, Guru dan Anak Didik Dalam Interaksi Edukatif, (Jakarta: PT Rineka Cipta, 2000), hlm. 47 


\section{Jenis Penelitian}

Penelitian ini termasuk jenis penelitian kuantitatif, dengan menjadikan Madrasah Ibtidaiyah Nurul Jihad Kecamatan Tembilahan Hulu sebagai lokasi penelitian. Penelitian ini menghabiskan waktu selama tiga bulan berturut-turut, mulai Februari sampai dengan April 2015. Ada 24 orang siswa di Madrasah Ibtidaiyah Nurul Jihad Kecamatan Tembilahan Hulu yang dijadikan sebagai subjek ${ }^{7}$ dalam penelitian ini. Sementara yang menjadi objek penelitian adalah, pengelolaan kelas terhadap motivasi belajar siswa kelas tinggi di Madrasah Ibtidaiyah Nurul Jihad Kecamatan Tembilahan Hulu tahun 2015.

\section{Teknik Pengumpulan Data}

Teknik pengumpulan data yang digunakan untuk dalam penelitian ini aadalah:

1) Observasi yaitu pengumpulkan data dengan jalan mengadakan pengamatan terhadap kegiatan yang sedang berlangsung. ${ }^{8}$ Dalam penelitian ini observasi dilakukan di kelas untuk melihat pengelolaan kelas, yang dilakukan oleh guru wali kelas pada kelas tinggi.

2) Angket merupakan serangkaian atau daftar pertanyaan yang disusun secara sistematis, kemudian dikirim untuk diisi oleh responden. Setelah diisi, angket dikirim kembali atau dikembalikan kepetugas atau peneliti. ${ }^{9}$ Dalam penelitian ini angket disebarkan kepada siswa kelas tinggi yang menjadi sampel dalam penelitian.

3) Dokumentasi adalah merupakan suatu teknik pengumpulan data dengan menghimpun dan menganalisis dokumen-dokumen, baik tertulis, gambar maupun elektronik. ${ }^{10}$ Dalam penelitian ini dokumentasi yang akan dicari adalah sejarah sekolah, keadaan sekolah, data guru dan siswa beserta data-data lain sebagai pendukung penelitian.

Peneliti melakukan pengumpulan data secara triangulasi, yaitu memadukan data-data yang dikumpulkan dari observasi, angket, dan dokumentasi.

\section{Teknik Analisis Data}

Data yang sudah terkumpul penulis kualifikasikan ke dalam angka-angka, sehingga data tersebut bersifat kuantitatif. Untuk selanjutnya, dianalisa dan di interpretasikan secara deskriptif.

Untuk memperoleh persentase pengelolaan kelas dan motivasi belajar siswa di Madrasah Ibtidaiyah Nurul Jihad Kecamatan Tembilahan Hulu, peneliti menggunakan rumus:

$$
\mathrm{P}=\frac{F}{\mathrm{~N}} \times 100 \%
$$

Ket : $\quad \mathrm{P}=$ Persentase

\footnotetext{
${ }^{7}$ Subjek adalah orang atau individu atau kelompok dijadikan unit atau satuan yang diteliti. Sanafiah Faisal, Format-Format Penelitian Sosial, (Jakarta: Raja Grafindo Persada, 2007), hlm. 109.

${ }^{8}$ Nana Syaodih Sukmadinata, Metode penelitian pendidikan, (Bandung: PT Remaja Rosdakarya, 2012), cet ke-8, hlm. 220

${ }^{9}$ Syofian Siregar, op.cit., hlm. 19

${ }^{10}$ Nana Syaodih Sukmadinata, op.cit., hlm. 221
} 
$\mathrm{F}=$ Frekuensi Persentase
$\mathrm{N}=$ Jumlah Frekuensi. ${ }^{11}$

Kemudian persentase pengelolaan kelas dan motivasi belajar siswa dapat diklasifikasikan sebagai berikut:

1. 81\%-100\% (pengelolaan kelas dan motivasi belajar siswa sangat baik).

2. 61\%-80\% (pengelolaan kelas dan motivasi belajar siswa baik).

3. 41\%-60\% (pengelolaan kelas dan motivasi belajar siswa cukup).

4. $21 \%-40 \%$ (pengelolaan kelas dan motivasi belajar siswa kurang baik).

5. $0 \%-20 \%$ (pengelolaan kelas dan motivasi belajar siswa sangat tidak baik). ${ }^{12}$

Sedangkan untuk mengetahui apakah terdapat pengaruh antara pengelolaan kelas terhadap motivasi belajar siswa di Madrasah Ibtidaiyah Nurul Jihad Kecamatan Tembilahan Hulu, peneliti menggunakan rumus Uji t.

Adapun langkah menentukan berpengaruh atau tidaknya pengelolaan kelas terhadap motivasi belajar siswa dicari dengan rumus Uji t:

Keterangan:

$$
t=\frac{\bar{x}-\bar{y}}{S^{2} x-y\left(\frac{1}{n x}+\frac{1}{n y}\right)}
$$

$$
\begin{array}{ll}
\mathrm{t} & =\text { nilai deviasi pada distribusi } \mathrm{t} \\
\overline{\mathrm{x}} & =\text { nilai rata-rata variabel } \mathrm{x} \\
\overline{\mathrm{y}} & =\text { nilai rata-rata variabel } \mathrm{y} \\
\mathrm{S}^{2} \mathrm{x}-\mathrm{y} & =\text { Standar Deviasi } \\
\mathrm{nx} & =\text { jumlah sampel } \mathrm{x} \\
\mathrm{ny} & =\text { jumlah sampel } \mathrm{y}^{13}
\end{array}
$$

Adapun langkah-langkah sebagai berikut:

1. Membuat Ha dan Ho dalam bentuk kalimat di bawah ini:

Ha: Ada pengaruh yang signifikan antara pengelolaan kelas terhadap motivasi belajar siswa pada kelas tinggi di Madrasah Ibtidaiyah Nurul Jihad kecamatan tembilahan hulu Tahun 2015.

Ho: Tidak ada pengaruh yang signifikan antara pengelolaan kelas terhadap motivasi belajar siswa pada kelas tinggi di Madrasah Ibtidaiyah Nurul Jihad kecamatan tembilahan hulu Tahun 2015.

2. Membuat hipotesis statistiknya:

Ha $: \mu_{x} \quad \neq \mu_{y}$

Ho: $\mu_{x} \quad=\mu_{y}$

3. Membuat tabel penolong.

4. Mencari nilai rata-rata variabel $\mathrm{X}$ dengan rumus :

Nilai $\bar{x}=\frac{\Sigma x}{n x}$

${ }^{11}$ Anas Sudijono, Pengantar Statistika Pendidikan, (Jakarta: RajaGrafindo Persada, 2008), hlm.

${ }^{12}$ Riduwan, Belajar Mudah Penelitian Untuk Guru-Karyawan dan Peneliti Pemula, (Bandung: Alfabeta, 2008), cet. 5, hlm. 89

${ }^{13}$ Herwati A, Modul Statistika Pendidikan, (Tembilahan, 2012), hlm. 21-22 
Selanjutnya mencari nilai rata-rata variabel y dengan rumus:

nilai $\bar{y}=\frac{\Sigma y}{n y}$

5. Selanjutnya mencari Varians $\left(S^{2} x-y\right)$ dengan rumus:

$$
\mathrm{S}^{2} \mathrm{x}-\mathrm{y}=\frac{\Sigma(x-\overline{\mathrm{x}})^{2}+\Sigma(y-\overline{\mathrm{y}})^{2}}{n x+n y-2}
$$

6. Menentukan nilai daviasi pada distribusi dengan menggunakan rumus $t_{\text {hitung }}$ :

$$
\mathrm{t}=\frac{\overline{\mathrm{x}}-\overline{\mathrm{y}}}{\mathrm{s}^{2} \mathrm{x}-\mathrm{y}\left(\frac{1}{\mathrm{nx}}+\frac{1}{\mathrm{ny}}\right)}
$$

7. membandingkan $t_{\text {tabel }}$ dan $t_{\text {hitung, }}$, sedangkan ttabel diperoleh dari $d f=n_{x}+n_{y}-2=24$

$+24-2=46$

kriteria :

jika $-\mathrm{t}_{\text {tabel }} \leq \mathrm{t}_{\text {hitung }} \leq \mathrm{t}_{\text {tabel }}$, maka Ho diterima.

\section{HASIL DAN PEMBAHASAN}

\section{Deskripsi Hasil Penelitian}

Data dalam penelitian ini, diperoleh melalui teknik pengumpulan data observasi dan angket. Observasi dilakukan kepada 6 guru wali kelas pada kelas tinggi, dan angket kepada 20 siswa kelas tinggi. Data yang diperoleh dari observasi dan angket tersebut, diolah dari data kualitatif menjadi data kuantitatif untuk keperluan analisis berikutnya. Selanjutnya data yang diperoleh dari observasi dan angket, diberi skor dengan ketentuan skor sebagai berikut:

Tabel 1

Observasi dan skor observasi

\begin{tabular}{cc}
\hline Alternatif jawaban & Skor \\
\hline Ya & 1 \\
Tidak & 0 \\
\hline
\end{tabular}

Jawaban dengan intensitas tinggi diberi bobot satu, dengan asumsi bahwa terlaksana dengan baik pengelolaan kelas di MI Nurul Jihad Kecamatan Tembilahan Hulu. Sedangkan jawaban dengan intensitas rendah diberi bobot nol, dengan asumsi bahwa tidak terlaksananya pengelolaan kelas di MI Nurul Jihad Kecamatan Tembilahan Hulu.

Tabel 2

Angket skor alternatif jawaban responden

\begin{tabular}{cc}
\hline Alternative Jawaban & Skor \\
\hline Selalu & 2 \\
Kadang-kadang & 1 \\
Tidak pernah & 0 \\
\hline
\end{tabular}

Dari tabel di atas terlihat bahwa alternatif jawaban dengan intensitas tinggi diberi bobot dua, dengan asumsi bahwa tingginya motivasi belajar siswa di MI Nurul Jihad Kecamatan Tembilahan Hulu. Sedangkan alternatif jawaban dengan intensitas 
cukup tinggi diberi bobot satu, dengan asumsi bahwa cukup tinggi motivasi belajar siswa di MI Nurul Jihad Kecamatan Tembilahan Hulu. Sedangkan alternatif jawaban dengan intensitas sangat rendah di beri bobot nol, dengan asumsi bahwa sangat rendah motivasi belajar siswa di MI Nurul Jihad Kecamatan Tembilahan Hulu.

Kemudian alternatif jawaban observasi yang telah dilakukan dan alternatif jawaban angket yang diperoleh dari setiap responden, selanjutnya dipersentasekan dengan menggunakan rumus sebagai berikut:

$\mathrm{P}=\frac{F}{\mathrm{~N}} \times 100 \%$

Ket $: \mathrm{P}=$ Persentase

$\mathrm{F}=$ Frekuensi Persentase

$\mathrm{N}=$ Jumlah Frekuensi. $^{14}$

\section{Penyajian data hasil observasi}

Penyajian data observasi pelaksanaan pengelolaan kelas oleh guru wali kelas, pada kelas tinggi di MI Nurul Jihad Kecamatan Tembilahan Hulu (Variabel $\mathrm{X})$.

Data observasi yang telah terkumpul, disajikan dan dianalisa dengan langkah-langkah sebagai berikut:

Tabel 4

Hasil rekapitulasi dan persentase observasi guru wali kelas MI Nurul Jihad dalam pengelolaan kelas terhadap motivasi belajar siswa Kecamatan Tembilahan Hulu

\begin{tabular}{|c|c|c|c|c|c|c|c|}
\hline \multirow{3}{*}{ No } & \multirow{3}{*}{ Indikator pengelolaan kelas } & \multicolumn{4}{|c|}{ Observasi } & \multirow{2}{*}{\multicolumn{2}{|c|}{ Jumlah }} \\
\hline & & \multicolumn{2}{|r|}{ Ya } & \multicolumn{2}{|c|}{ Tidak } & & \\
\hline & & $\mathbf{F}$ & $\mathbf{P}(\%)$ & $\mathbf{F}$ & $\mathbf{P}(\%)$ & $\mathbf{F}$ & $\mathbf{P}(\%)$ \\
\hline 1 & Guru mengatur tempat duduk siswa & 24 & $100 \%$ & 0 & $0 \%$ & 24 & $100 \%$ \\
\hline 2 & $\begin{array}{l}\text { Guru mengatur alat peraga, atau media } \\
\text { pengajaran }\end{array}$ & 18 & $75 \%$ & 6 & $25 \%$ & 24 & $100 \%$ \\
\hline 3 & Guru mengatur hiasan dinding & 24 & $100 \%$ & 0 & $0 \%$ & 24 & $100 \%$ \\
\hline 4 & $\begin{array}{l}\text { Guru mengatur pemeliharaan kebersihan } \\
\text { kelas }\end{array}$ & 24 & $100 \%$ & 0 & $0 \%$ & 24 & $100 \%$ \\
\hline 5 & Guru mengatur ventilasi dan tata cahaya & 24 & $100 \%$ & 0 & $0 \%$ & 24 & $100 \%$ \\
\hline 6 & $\begin{array}{l}\text { Guru menciptakan kehangatan dalam } \\
\text { belajar }\end{array}$ & 24 & $100 \%$ & 0 & $0 \%$ & 24 & $100 \%$ \\
\hline 7 & $\begin{array}{l}\text { Guru menciptakan rasa keantusiasan } \\
\text { pada iri siswa }\end{array}$ & 24 & $100 \%$ & 0 & $0 \%$ & 24 & $100 \%$ \\
\hline 8 & $\begin{array}{l}\text { Guru menggunakan bahan yang } \\
\text { menantang untuk meningkatkan gairah } \\
\text { belajar siswa }\end{array}$ & 13 & $54,17 \%$ & 11 & $45,83 \%$ & 24 & $100 \%$ \\
\hline 9 & $\begin{array}{l}\text { Guru mempertimbangkan penggunaan } \\
\text { gaya mengajar }\end{array}$ & 23 & $95,83 \%$ & 1 & $4,17 \%$ & 24 & $100 \%$ \\
\hline 10 & Guru memperhatikan pola interaksi & 24 & $100 \%$ & 0 & $0 \%$ & 24 & $100 \%$ \\
\hline
\end{tabular}

${ }^{14}$ Anas Sujdijono, Pengantar Statistik Pendidikan, (Jakarta: Raja Grafindo Persada, 2008), hlm. 


\begin{tabular}{|c|c|c|c|c|c|c|c|}
\hline mon & I. & tidai & & SN: & $\begin{array}{l}\text { 443-0021 } \\
\text { Nur Asisa }\end{array}$ & $\begin{array}{r}J . \\
\text { ISSN } \\
\text { Nasi }\end{array}$ & $\begin{array}{l}\text { itra PGMI } \\
2716-4136 \\
\text { lah }(2020)\end{array}$ \\
\hline 11 & $\begin{array}{l}\text { Guru memiliki keluwesan tingkah } \\
\text { lakudalam mengajarnya untuk mencengah } \\
\text { gangguan yang timbul }\end{array}$ & 16 & $66,67 \%$ & 8 & $33,33 \%$ & 24 & $100 \%$ \\
\hline 12 & $\begin{array}{l}\text { Guru menekankan hal yang positif dan } \\
\text { menghindari pemusatan perhatian siswa } \\
\text { pada hal negatif }\end{array}$ & 8 & $33,33 \%$ & 16 & $66,67 \%$ & 24 & $100 \%$ \\
\hline 13 & 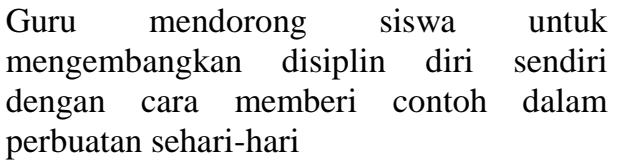 & 24 & $100 \%$ & 0 & $0 \%$ & 24 & $100 \%$ \\
\hline & Jumlah & 270 & & 42 & & 312 & \\
\hline
\end{tabular}

Dari hasil rekapitulasi, maka data hasil observasi pengelolaan kelas dengan menggunakan rumus:

$$
\begin{aligned}
& \mathrm{P}=\frac{F}{\mathrm{~N}} \times 100 \% \\
& \text { Ket }: \quad \mathrm{P}=\text { Persentase } \\
& \mathrm{F}=\text { Frekuensi Persentase } \\
& \mathrm{N}=\text { Jumlah Frekuensi }
\end{aligned}
$$

Sehingga dapat ditentukan persentase, dari masing-masing alternatif jawaban yang di sajikan sebagai berikut:

1. Alternatif jawaban Ya $270 \times 1=270$

2. Alternatif jawaban Tidak $42 \times 0=0$

Dari bobot alternatif jawaban di atas, maka diperoleh nilai $F=270$. Sedangkan nilai $\mathrm{N}$ diperoleh dari jumlah aspek yang diamati $\mathrm{x}$ jumlah observasi $\mathrm{x}$ skor tertinggi option observasi x jumlah responden, sehingga diperoleh hasil $\mathrm{N}=13$ x 4 x 1 x $6=312$. Jadi persentase akhir dari pelaksanaan pengelolaan kelas adalah:

$$
\mathrm{P}=\frac{F}{\mathrm{~N}} \times 100 \%=\frac{270}{312} \times 100 \%=\frac{27000}{312}=86,54 \%
$$

Berdasarkan persentase di atas dan disesuaikan dengan klasifikasi persentase, maka pelaksanaan pengelolaan kelas di MI Nurul Jihad Kecamatan tembilahan Hulu dikategorikan sangat baik, karena angka 86,54\% terletak pada interval 81\%-100\%.

\section{Penyajian Data Angket}

Teknik angket digunakan untuk memperoleh data yang berhubungan dengan motivasi belajar siswa, di MI Nurul Jihad Kecamatan Tembilahan Hulu. Angket ini berisi pertanyaan yang terdiri dari 8 pertanyaan dengan 3 alternatif jawaban, yang disebarkan kepada 24 siswa kelas tinggi. Penyebaran angket dimulai pada tanggal 22 Agustus 2015, hingga 26 Agustus 2015.

Data angket yang telah terkumpul, disajikan dalam bentuk rekap dan persentase. Berikut ini adalah hasil angket motivasi belajar siswa, di MI Nurul Jihad Kecamatan Tembilahan Hulu. 
Tabel 6

Rekapitulasi dan Persentase Data Hasil Angket motivasi belajar siswa

\begin{tabular}{|c|c|c|c|c|c|c|c|c|c|}
\hline \multirow{3}{*}{ No } & \multirow{3}{*}{$\begin{array}{l}\text { Indikator motivasi } \\
\text { belajar siswa }\end{array}$} & \multicolumn{6}{|c|}{ Alternatif jawaban } & \multirow{2}{*}{\multicolumn{2}{|c|}{ Jumlah }} \\
\hline & & \multicolumn{2}{|c|}{$\mathbf{A}$} & \multicolumn{2}{|c|}{ B } & \multicolumn{2}{|r|}{$\mathbf{C}$} & & \\
\hline & & $\mathbf{F}$ & $\mathbf{P}(\%)$ & $\mathbf{F}$ & $\mathbf{P}(\%)$ & $\mathbf{F}$ & $\mathbf{P}(\%)$ & $\mathbf{F}$ & $\mathbf{P}(\%)$ \\
\hline 1 & $\begin{array}{l}\text { memiliki hasrat dalam } \\
\text { belajar }\end{array}$ & 19 & $79,17 \%$ & 5 & $20,83 \%$ & 0 & $0 \%$ & 24 & $100 \%$ \\
\hline 2 & $\begin{array}{l}\text { memiliki keinginan } \\
\text { berhasil dalam belajar }\end{array}$ & 22 & $91,67 \%$ & 2 & $8,33 \%$ & 0 & $0 \%$ & 24 & $100 \%$ \\
\hline 3 & $\begin{array}{l}\text { mendapatkan dorongan } \\
\text { dari guru dalam belajar }\end{array}$ & 7 & $29,17 \%$ & 16 & $66,66 \%$ & 1 & $4,17 \%$ & 24 & $100 \%$ \\
\hline 4 & $\begin{array}{l}\text { mendapatkan kebutuhan } \\
\text { dalam belajar }\end{array}$ & 13 & $54,17 \%$ & 11 & $45,83 \%$ & 0 & $0 \%$ & 24 & $100 \%$ \\
\hline 5 & $\begin{array}{l}\text { memiliki harapan dan } \\
\text { cita-cita masa depan }\end{array}$ & 17 & $70,83 \%$ & 6 & $25 \%$ & 1 & $4,17 \%$ & 24 & $100 \%$ \\
\hline 6 & $\begin{array}{l}\text { diberikan penghargaan } \\
\text { dalam belajar }\end{array}$ & 6 & $25 \%$ & 6 & $25 \%$ & 12 & $50 \%$ & 24 & $100 \%$ \\
\hline 7 & $\begin{array}{l}\text { diberikan kegiatan yang } \\
\text { menarik dalam belajar }\end{array}$ & 0 & $0 \%$ & 7 & $29,17 \%$ & 17 & $70,83 \%$ & 24 & $100 \%$ \\
\hline 8 & $\begin{array}{l}\text { memiliki lingkungan } \\
\text { belajar yang kondusif } \\
\text { sehingga memungkin kan } \\
\text { peserta didik dapat } \\
\text { belajar dengan baik }\end{array}$ & 2 & $8,33 \%$ & 15 & $62,5 \%$ & 7 & $29,17 \%$ & 24 & $100 \%$ \\
\hline & jumlah & 86 & & 68 & & 38 & & 192 & \\
\hline
\end{tabular}

Dari hasil rekapitulasi, maka data kompetensi pedagogik guru dianalisis dengan menggunakan rumus:

$$
\mathrm{P}=\frac{F}{\mathrm{~N}} \times 100 \%
$$

Ket : $\mathrm{P}=$ Persentase

$$
\begin{aligned}
\mathrm{F}= & \text { Frekuensi Persentase } \\
\mathrm{N}= & \text { Jumlah Frekuensi (jumlah responden } \mathrm{x} \text { jumlah pertanyaan angket). } \\
& \text { Jadi, nilai } \mathrm{N}=24 \times 8=192 .
\end{aligned}
$$

Sehingga dapat ditentukan, persentase dari masing-masing alternatif jawaban yang disajikan sebagai berikut:

1. Alternatif jawaban $A=\frac{86}{192} \times 100 \%=44,80 \%$

2. Alternatif jawaban $\mathrm{B}=\frac{68}{192} \times 100 \%=35,41 \%$

3. Alternatif jawaban $\mathrm{C}=\frac{38}{192} \times 100 \%=19,79 \%$

Sedangkan untuk mendapatkan persentase akhir, maka masing-masing alternatif jawaban diberi bobot sebagai berikut :

1. Alternatif jawaban $A=86 \times 2=172$

2. Alternatif jawaban $\mathrm{B}=68 \times 1=68$

3. Alternatif jawaban $\mathrm{C}=38 \times 0=0$ 
Dari bobot alternatif jawaban di atas, maka diperoleh nilai $\mathrm{F}=172+68+0=$ 240. Sedangkan nilai $\mathrm{N}$ diperoleh dari jumlah item pertanyaan $\mathrm{x}$ skor tertinggi alternatif jawaban x jumlah responden, sehingga diperoleh hasil $\mathrm{N}=8 \times 2 \times 24=384$. Jadi persentase akhir dari motivasi belajar siswa adalah :

$\mathrm{P}=\frac{F}{\mathrm{~N}} \times 100 \%=\frac{240}{384} \times 100 \%=\frac{24000}{384}=62,5 \%$

Berdasarkan persentase di atas dan disesuaikan dengan klasifikasi persentase, maka motivasi belajar siswa di MI Nurul Jihad Kecamatan Tembilahan Hulu dikategorikan baik, karena angka 62,5\% terletak pada interval $61 \%-80 \%$.

Berikutnya, untuk melakukan pembahasan terhadap data hasil penelitian ditempuh langkah-langkah sebagai berikut:

\section{Langkah Pertama:}

Membuat Ha dan Ho dalam bentuk kalimat di bawah ini:

Ha: Ada pengaruh yang signifikan antara pengelolaan kelas terhadap motivasi belajar siswa pada kelas tinggi di Madrasah Ibtidaiyah Nurul Jihad kecamatan tembilahan hulu Tahun 2015.

Ho: Tidak ada pengaruh yang signifikan antara pengelolaan kelas terhadap motivasi belajr siswa pada kelas tinggi di Madrasah Ibtidaiyah Nurul Jihad kecamatan tembilahan hulu Tahun 2015.

\section{Langkah Kedua:}

Membuat Ha dan Ho dalam bentuk statistik, yaitu:

Ha : $\mu_{x} \neq \mu_{y}$

Ho : $\mu_{x}=\mu_{y}$

\section{Langkah ketiga:}

Membuat tabel penolong, untuk menghitung angka statistik, dimana untuk tabel $\mathrm{X}$ merupakan jumlah observasi yang dilakukan terhadap 6 guru wali kelas sebanyak 4 kali observasi untuk masing-masing guru. Sedangkan untuk tabel Y, merupakan jumlah sampel siswa yakni 24 orang.

Tabel 7

Tabel Penolong Statistik

\begin{tabular}{|c|c|c|c|c|c|c|c|}
\hline $\begin{array}{c}\text { Guru yang di } \\
\text { observasi }\end{array}$ & $\mathbf{X}$ & Nama sampel siswa & $\mathbf{Y}$ & $\mathbf{X}-\overline{\mathbf{X}}$ & $(\mathrm{X}-\overline{\mathrm{X}})^{2}$ & $\mathbf{Y}-\overline{\mathbf{Y}}$ & $(\mathbf{Y}-\overline{\mathbf{Y}})^{2}$ \\
\hline Sayani obs. 1 & 10 & Abib abdurahman & 13 & $\begin{array}{c}10-11,25 \\
=-1,25\end{array}$ & 1,5625 & $\begin{array}{c}13-10 \\
=3\end{array}$ & 9 \\
\hline Sayani obs. 2 & 10 & Puji astuti & 9 & $-1,25$ & 1,5625 & -1 & 1 \\
\hline Sayani obs. 3 & 11 & Rama pratama putra & 8 & $-0,25$ & 0,0625 & -2 & 4 \\
\hline Sayani obs. 4 & 13 & Safaiza & 9 & 1,75 & 3,0625 & -1 & 1 \\
\hline Agus salim obs. 1 & 12 & Nada sherly rilviana & 13 & 0,75 & 0,5625 & 3 & 9 \\
\hline Agus salim obs. 2 & 12 & Yusniyarti & 9 & 0,75 & 0,5625 & -1 & 1 \\
\hline Agus salim obs. 3 & 12 & Barnas & 9 & 0,75 & 0,5625 & -1 & 1 \\
\hline Agus salim obs. 4 & 13 & M.fikri ardiansyah & 6 & 1,75 & 3,0625 & -4 & 16 \\
\hline Salmah obs. 1 & 11 & Indah fitria $r$ & 10 & $-0,25$ & 0,0625 & 0 & 0 \\
\hline Salmah obs. 2 & 11 & Nurul hidayah & 10 & $-0,25$ & 0,0625 & 0 & 0 \\
\hline Salmah obs. 3 & 11 & M.afrizal & 9 & $-0,25$ & 0,0625 & -1 & 1 \\
\hline Salmah obs. 4 & 12 & Eko s & 13 & 0,75 & 0,5625 & 3 & 9 \\
\hline
\end{tabular}


Prodi Pendidikan Guru Madrasah Ibtidaiyah STAI AuliaurrasyidinTembilahan
ISSN: 2443-0021 e-ISSN: 2716-4136

Nur Asisah, Nasrullah (2020)

Febri herlini obs.

Febri herlini obs.2

10 M.salim

Febri herlini obs. 3

10 Nur aisa

10 Rabiatul a

Febri herlini obs.4

12

Fami hartini obs.1

Fami hartini obs.2

M.arsil fadli

11 Nurhayati

Fami hartini obs. 3

Fami hartini obs. 4

Mansah

M.uddni

Dewi safitri

M.risqullah

Asmawati obs. 2

11 Intan nuraini

$-1,25$

1,5625

$-1,25$

1,5625

$-1,25$

1,5625

0,75

0,5625

$-0,25 \quad 0,0625$

$-0,25 \quad 0,0625$

$-0,25 \quad 0,0625$

$0,75 \quad 0,5625$

$-1,25 \quad 1,5625$

$-0,25$

0,0625

Asmawati obs.3

12 Nur hidayah

0,75

Ahmad afandi

270

11

0,75

0,5625

0,5625

\begin{tabular}{cc}
-1 & 1 \\
1 & 1 \\
1 & 1 \\
-2 & 4 \\
4 & 16 \\
-1 & 1 \\
-2 & 4 \\
2 & 4 \\
-3 & 9 \\
0 & 0 \\
2 & 4 \\
1 & 1 \\
\hline
\end{tabular}

\section{Langkah ke empat:}

Mencari rata-rata variabel $\mathrm{X}$ dan variabel $\mathrm{Y}$ :

1. Rata-rata variabel $X$

$$
\bar{X}=\sum X=\underline{270}=11,25
$$

$$
\text { nx } 24
$$

dengan demikian diketahui bahwa rata-rata variabel $\mathrm{X}$ : 11,25

2. Rata-rata variabel $Y$

$$
\overline{\mathrm{Y}}=\sum \mathrm{Y}=\underline{240}=10
$$

ny 24

Dengan demikaian diketahui bahwa rata-rata variabel Y : 10

\section{Langkah ke lima:}

Mencari varians $\left(\mathrm{S}^{2} \mathrm{x}-\mathrm{y}\right)$ dengan rumus :

$$
\begin{aligned}
& \mathrm{S}_{\mathrm{x}-\mathrm{y}}^{2}=\frac{\Sigma(x-\overline{\mathrm{x}})^{2}+\Sigma(y-\overline{\mathrm{y}})^{2}}{n x+n y-2} \\
& \mathrm{~S}_{\mathrm{x}-\mathrm{y}}^{2}=\frac{20,5+98}{24+24-2} \\
& \mathrm{~S}_{\mathrm{x}-\mathrm{y}}^{2}=\frac{118,5}{46} \quad \mathrm{~S}_{\mathrm{x}-\mathrm{y}}^{2}=\mathbf{2 , 5 7 6}
\end{aligned}
$$

\section{Langkah ke enam:}

Menentukan nilai daviasi pada distribusi dengan menggunakan rumus $t$ hitung:

$$
\begin{aligned}
& t=\frac{\bar{x}-\bar{Y}}{\sqrt{S_{x-y}^{2}\left(\frac{1}{n_{x}}+\frac{1}{n_{y}}\right)}} \\
& t=\frac{11,25-10}{\sqrt{2,576\left(\frac{1}{24}+\frac{1}{24}\right)}} \\
& t=\frac{1,25}{\sqrt{2,576(0,041+0,041)}} \\
& t=\frac{1,25}{\sqrt{2,576(0,082)}} \\
& t=\frac{1,25}{\sqrt{0,211}}
\end{aligned}
$$




$$
\begin{aligned}
& t=\frac{1,25}{0,459} \\
& t=2,723
\end{aligned}
$$

\section{Langkah ke tujuh:}

Membandingkan ttabel dan thitung. Sedangkan $t$ tabel diperoleh dari df (derajat kebebasan) dengan rumus:

$$
\begin{aligned}
\mathrm{df} & =\mathrm{n} 1+\mathrm{n} 2-2 \\
& =24+24-2 \\
& =46
\end{aligned}
$$

Kriteria: $\mathrm{Jika}-\mathrm{t}_{\text {tabel }} \leq \mathrm{t}_{\text {hitung }} \leq \mathrm{t}_{\text {tabel }}$, maka Ho diterima

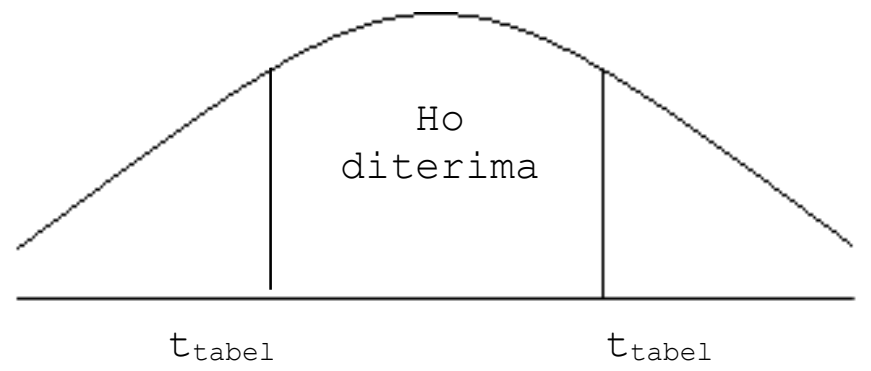

\section{Kesimpulan:}

$\alpha=0,05$

$\mathrm{df}=\mathrm{n} 1+\mathrm{n} 2-2=24+24-2=46$

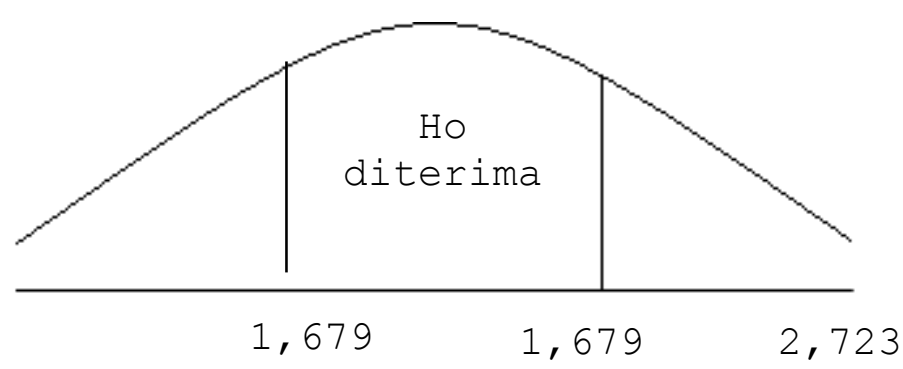

Karena $t_{\text {hitung }}$ terletak pada daerah penolakan maka Ho ditolak.

Kesimpulan:

Terdapat pengaruh yang signifikan antara pengaruh pengelolaan kelas terhadap motivasi belajar siswa di Madrasah Ibtidaiyah Nurul Jihad Kecamatan Tembilahan Hulu.

\section{Keterangan:}

Berdasarkan $t_{\text {tabel }}$, diketahui bahwa nilai untuk 46 tidak ada, maka diambil nilai yang terdekat yaitu 45 . Dan nilai untuk 45 adalah 1,679 . Karena $t_{\text {hitung }} \geq t_{\text {tabel, }}$, maka Ho ditolak, Ha diterima, artinya ada pengaruh yang signifikan. 


\section{Analisa Data Hasil Penelitian}

Adapun data hasil observasi terhadap variabel $\mathrm{X}$, dapat dianalisa bahwa pengelolaan kelas di Madrasah Ibtidaiyah Nurul Jihad Kecamatan Tembilahan Hulu, mencapai angka 86,54\% dan dikategorikan sangat baik, karena angka 86,54\% terletak pada interval $81 \%-100 \%$. Sedangkan data hasil angket terhadap variabel Y, dapat dianalisa bahwa motivasi belajar siswa di Madrasah Ibtidaiyah Nurul Jihad Kecamatan Tembilahan Hulu, mencapai angka 62,5\%, dan dikategorikan baik, karena angka 62,5\% terletak pada interval $61 \%-80 \%$.

Berdasarkan data melalui observasi terhadap variabel $\mathrm{X}$ dan angket pada variabel $\mathrm{Y}$, dapat dianalisa bahwa terdapat pengaruh yang signifikan antara pengaruh pengelolaan kelas terhadap motivasi belajar siswa di Madrasah Ibtidaiyah Nurul Jihad Kecamatan Tembilahan Hulu, yang ditunjukkan dengan angka 2,723 dan diinterpretasikan cukup tinggi. Karena berdasarkan t tabel, nilai untuk 45 adalah 1,679. Sehingga $t_{\text {hitung }} \geq t_{\text {tabel }}$, artinya $2,723 \geq 1,679$, maka Ha diterima, angka 2,723 terletak pada daerah penolakan, maka Ho ditolak dan Ha diterima.

\section{KESIMPULAN}

Berdasarkan uraian dari keseluruhan pembahasan dan analisis dalam penelitian ini, maka penulis dapat mengambil kesimpulan sesuai dengan rumusan masalah yang telah diuraikan sebagai berikut: Pengelolaan kelas oleh guru wali kelas pada kelas tinggi IV, V, dan VI, di Madrasah Ibtidaiyah Nurul Jihad Kecamatan Tembilahan Hulu dikategorikan baik. Hal ini terbukti dari persentase akhir data observasi, yaitu 86,54\%. Begitu pula dengan motivasi belajar siswa, di Madrasah Ibtidaiyah Nurul Jihad Kecamatan Tembilahan Hulu dikategorikan baik. Hal tersebut terbukti dari persentase akhir data angket, yaitu 62,5\%. Selain itu, hal terpenting yang menjadi kesimpulan dalam penelitian ini dan sekaligus menjawab rumusan masalah adalah terdapat pengaruh yang signifikan antara pengelolaan kelas terhadap motivasi belajar siswa di Madrasah Ibtidaiyah Nurul Jihad Kecamatan Tembilahan Hulu. Hal ini terbukti dari hasil akhir uji t, dengan varians (pengujian signifikansi) antara variabel bebas (X) dengan variabel terikat (Y), yang menggambarkan bahwa perolehan ${ }_{t}$ Hitung adalah $2,723 \geq$ (lebih besar dari) tTabel adalah 1,679 dengan taraf signifikansi 0,05.

\section{DAFTAR PUSTAKA}

Asril, Zainal. 2012. Micro Teaching. Jakarta: Rajawali Pers.

Bungin, Burhan. 2013. Metodologi Penelitian Kuantitatif. Jakarta: Kencana.

Kamus Bahasa Indonesia untuk Pelajar, Jakarta: Badan Pengembangan dan Pembinaan Bahasa Kementrian Pendidikan dan Kebudayaan, 2011, Cet. Ke-1

Djalil, Aria. 2002. Materi pokok pembelajaran kelas rangkap; 1-6 PGSD2105/2SKS. Jakarta: Pusat Penerbitan Universits Terbuka.

Djamarah, Syaiful Bahri dan Aswan Zain. 2006. Strategi Belajar Mengajar. Jakarta: Rineka Cipta. 
Rineka Cipta.

Evertson, Carolyn M dan Edmund T. Emmer. 2011. Manajemen Kelas Untuk Guru Sekolah Dasar. Jakarta: Kencana Prenada Media Group.

Hamalik, Omar. 2011. Proses Belajar Mengajar. Jakarta: PT Bumi Aksara.

Herwati A. 2012. Modul Statistika Pendidikan. Tembilahan.

Kurdi, Syuaeb dan Abdul Aziz. 2006. Model Pembelajaran Efektif Pendidikan Agama Islam di SD dan MI. Bandung: Pustaka Bani Quraisy.

Riduwan. 2008. Belajar Mudah Penelitian Untuk Guru-Karyawan dan Peneliti Pemula. Bandung: Alfabeta.

Sardiman. 2007. Interaksi dan Motivasi Belajar Mengajar. Jakarta : PT Raja Grafindo Persada.

Siregar, Syofian. 2014. Merode Penelitian Kuantitatif. Jakarta: Kencana.

Sujdijono, Anas. 2008. Pengantar Statistika Pendidikan. Jakarta: RajaGrafindo Persada.

Sukmadinata, Nana Syaodih. 2012. Metode penelitian pendidikan. Bandung: PT Remaja Rosdakarya.

Sulistyorini. 2009. Manajemen Pendidikan Islam, Konsep, Strategi dan Aplikasi. Yogyakarta: Teras.

Suprijono, Agus. 2012. Cooperative Learning. Yogyakarta: Pustaka Belajar.

Suyadi. 2010. Psikolologi Pendidikan Anak Usia Dini. Yogyakarta: PT Pustaka Insan Madani, Anggota IKAPI.

Syah, Hidayat. 2010. Pengantar umum metodologi penelitian pendididkan pendekatan verifikati. Pekan baru: Suska Press.

Usman, Moh Uzer. 2004. Menjadi Guru Profesional. Bandung: PT Remaja Rosdakarya. 